\title{
Economic and social structures of water buffalo farming in Muş province of Turkey
}

\author{
Mehmet Işik', Mevlüt Gül² \\ ${ }^{1}$ Ministry of Food, Agriculture and Livestock, Isparta Provincial Directorate of Food, Agriculture and Livestock, Isparta, Turkey. \\ ${ }^{2}$ Süleyman Demirel University, Faculty of Agriculture, Department of Agricultural Economics, Isparta, Turkey.
}

\begin{abstract}
The purpose of this study was to analyse the socio-economic structure of water buffalo farming in the province of Muş, in Turkey. The stratified sampling method was used to calculate sample size of buffalo farms in the Central, Korkut, and Hasköy districts of Muş province, where buffalo farming is widespread. Data were collected from the 94 farms by surveys in the 2013 production period. A single budget analysis method was used to calculate production cost and profit for water buffaloes. Plant production constituted $37.85 \%$ of the gross production value, while animal production accounted for $62.15 \%$. The biggest share in the gross production value derived from water buffalo farming (45.71\%). Fixed and variable costs were $51.44 \%$ and $48.56 \%$ of the production cost (USD11691.06), respectively. The largest part of the variable cost was the feed cost $(75.81 \%)$. The cost of per kilogram buffalo milk in the region was calculated as USD0.64. Consequently, it is important to ensure the continuation of breeding studies to increase milk yield, giving information to farmers about modern techniques, developing policies to increase the scale of the farms, and implementing regional and national policies to increase awareness of buffalo milk and milk products.
\end{abstract}

Key Words: production cost, profit, structure

\section{Introduction}

Water buffaloes in different regions have an economic value that is specific to their own region. Especially, the unique quality of their milk and dairy products increase their value. Italian Mozzarella cheese, which is famous throughout the world, is made from water buffalo milk. Also, water buffalo farming has advantages related to the resistance of water buffaloes to natural conditions and diseases, their ability to benefit from feed and to turn poor feed into meat and milk, and finally, their low cost compared with cows (Canbolat, 2012).

Water buffaloes in Turkey are believed to have originated from Mediterranean water buffaloes, which are a sub-group of river water buffaloes, and are called Anatolian water buffaloes (Soysal, 2006).

According to data from the Turkish Statistical Institute (TUIK, 2015), water buffalo farming in Turkey is concentrated in the coastal Black Sea region in the provinces

Received October 19, 2015 and accepted April 4, 2016.

Corresponding author: mevlutgul@sdu.edu.tr

http://dx.doi.org/10.1590/S1806-92902016000700007

Copyright (C) 2016 Sociedade Brasileira de Zootecnia. This is an Open Access article distributed under the terms of the Creative Commons Attribution License (http://creativecommons.org/licenses/by/4.0/), which permits unrestricted use, distribution, and reproduction in any medium, provided the original work is properly cited. of Samsun and Sinop; in the central Black Sea region in Tokat, Çorum, and Amasya; in Sivas and Yozgat in central Anatolia; in Afyon in the Aegean region; in İstanbul in the Marmara region; in Muş in the East Anatolia region; and in Diyarbakır in the South-East Anatolia region.

Muş province was chosen as the research area in this study as one of the important provinces for water buffalo farming in the East Anatolia region in Turkey. Few studies of water buffalo farming have been found as a result of a literature review. There are no studies on water buffalo farming in Muş province. Agriculture is the major source of income in the province, and the pasture and meadow areas suitable for livestock have a high potential for new investments. The number of water buffaloes was 13749 head in 1991, and declined sharply to 3296 head in 2009. After this year, it started to increase with animal husbandry support by the government.

The main purpose of this study was to determine the current conditions of water buffalo production activity to contribute to future policies.

The study was carried out to describe the socialeconomic characteristics of water buffalo farmers; measure water buffalo production performance in the study area; determine the production cost and returns of water buffalo production; and determine the major problems water buffalo farmers are facing. 


\section{Material and Methods}

The study was carried out in Muş province, in East Anatolian Region of Turkey. Muş covers approximately $8196 \mathrm{~km}^{2}$ in land area, which is about $1.1 \%$ of the total land area of Turkey. Muss is located between $38^{\circ} 29^{\prime}$ and $39^{\circ} 29^{\prime}$ North latitudes and between $41^{\circ} 06^{\prime}$ and $41^{\circ} 47^{\prime}$ East longitudes. Agriculture is the major source of income for the majority of the people in the province, although it is not developed enough to be integrated with the industry. The share of employment in the agricultural sector is $56 \%$ in Mus province. This rate is well above the average of Turkey (23\%) (TUIK, 2014).

A large number of farmers in Muş province depend on animal husbandry (cattle, sheep, goat, and water buffaloes) for their livelihood. The study areas contribute significantly to the production of field and forage crops such as wheat and alfalfa (TUIK, 2015).

The number of water buffaloes was 13749 head in 1991, and declined to 6970 head in 2000, 5292 head in 2005, and 3296 head in 2009. After this year, it reached 6098 head with the animal husbandry support in 2014 (TUIK, 2015).

The main material of this study came from the data collected from the water buffalo farms by the survey method. A secondary source of material was provided from institutions like FAO, TUIK, and the provincial Directorate of Food, Agriculture and Livestock. In addition, local and international studies on this subject were used. The data used in this study were from the production period of 2013.

Water buffalo farming in Mus is concentrated in the Central, Korkut, and Hasköy districts of the province. According to records from the provincial Directorate of Food, Agriculture and Livestock, $16 \%$ of the water buffaloes are in the Centre, $28 \%$ in Korkut, and $17 \%$ in Hasköy districts in Muş. It was not possible to interview all the farms for reasons of cost and time. Farms were selected by the stratified sampling method. The number of farms to be interviewed was decided by the stratified sampling method (Yamane, 2001). Distribution of sample farms to layers was made by using the Neyman Method (Çiçek and Erkan, 1996).

Sample size (number of farms to be interviewed) was calculated as 94 with confidence limits of $95 \%$ and an average of $5 \%$ deviation. Buffalo farms were divided into four groups based on the number of water buffaloes they had in the study. Accordingly, the first group (34 farms) was composed of farms with 1 to 4 head of water buffaloes; the second group (30 farms) was composed of farms with 5 to 11 head of water buffaloes; the third group (13 farms) was composed of farms with 12 to 19 head of water buffaloes; and, finally, the fourth group (17 farms) was composed of farms with 20 and more head (Table 1).

The data were collected from water buffalo farms by the survey method. Data collection methods used in agricultural economic studies are mostly techniques that classify survey, observation, and focus groups. Generally, the survey method is the most commonly preferred. Questionnaires were filled completely by asking questions during visits to the farms. Information included on the survey questionnaires can be summarized as follows: population and family labour force in the farms; outsider labour force in the farms; land size of the farms; agricultural production condition of the farms and the way the products are used; implements and machinery capital of the farms; roughage and feed concentrate stocks of the farms; water buffaloes of the farms; products obtained from the water buffaloes and ways to use them; daily consumption of feed by the water buffaloes; other costs of water buffaloes; condition of housing; daily work concerning water buffaloes; time and land for water buffalo grazing; relation of farms with technology; amount of loan, interests of the farms; problems faced by water buffalo farms; and positions and conclusions of the farms about the policies implemented for water buffalo farming.

A single product budget analysis was used to analyse the costs of the farms. Absolute profit, relative profit, and gross profit were calculated. The main purpose of an enterprise is to find ways to increase its profit. The difference between the value of gross output and production cost is absolute profit, or net profit (Kiral et al., 1999). For calculation of gross output and absolute profit, the following formulas were used (Açıl and Demirci, 1984; Kıral et al., 1999):

$$
\mathrm{GP}=\mathrm{GPV}-\mathrm{VC} \text {, }
$$

in which GP: gross profit; GPV: gross output value; and VC: variable cost.

$$
\mathrm{AP}=\mathrm{GVWB}-\mathrm{PCWB},
$$

in which AP: absolute profit; GVWB: value of gross output of water buffalo farms; and PCWB: production cost of water buffalo farms.

Table 1 - Sampling size

\begin{tabular}{lcc}
\hline Group of farms & $\begin{array}{c}\text { Number of water buffaloes } \\
\text { (head) }\end{array}$ & $\begin{array}{c}\text { Sample size } \\
\text { (interviewed farm number) }\end{array}$ \\
\hline I & $1-4$ & 34 \\
II & $5-11$ & 30 \\
III & $12-19$ & 13 \\
IV & 20 head and more & 17 \\
Total & & 94 \\
\hline
\end{tabular}


Relative profit: This is the ratio of the value of gross output to production cost. It shows how one option is relatively superior to another. Relative profit better evaluates the gains of production activities.

$$
\mathrm{RP}=\mathrm{GVWB} / \mathrm{PCWB} \text {, }
$$

in which RP: relative profit.

The chi-squared test was used to identify the relations among observed variables. For continuous variables, analysis of variance was used. Relations that had statistical differences were indicated. The potential of the family labour force was converted to male labour units. The population with the ability and the appropriate age to work was multiplied by the number of days of work in the region. In this way, the family labour force potential was stated as male labour units (Aras and Çakır, 1975; Açıl and Demirci, 1984; Rehber and Çetin, 1998). The value of gross output includes the sale value of dairy products, productive value increases, and the value of fertilizer (Erkuş et al., 1996).

Productive value increase was calculated with the following formula (Kiral et al., 1999):

$$
\begin{gathered}
\text { PVI }=(\text { VWBend }+ \text { VWBsold }+ \text { VWBsla })-(\text { VWBbe }+ \\
\text { VWBpur }),
\end{gathered}
$$

in which PVI: productive value increase (USD); VWBend: value of the water buffalo head at the end of the period (USD); VWBsold: value of the water buffaloes that are sold (USD); VWBsla: value of the water buffaloes that are slaughtered (USD); VWBbe: value of the water buffalo head at the beginning of the period (USD); and VWBpur: value of the water buffaloes that are purchased (USD).

Enterprise loan was decided based on the statement of the enterprise owner. The value of the daily labour of the family members and enterprise owner was calculated according to payments for labour in the region. Depreciation rates of adobe buildings, stone buildings, and concrete buildings for water buffaloes were $4 \%, 3 \%$, and $5 \%$, respectively (Yıldırım and Şahin, 2003). The following formula was used to calculate the interest of the capital of water buffaloes (Erkuş et al., 1996):

$$
\mathrm{ICWB}=[(\mathrm{VBWB}-\mathrm{BVWB}) / 2)+\mathrm{BVWB}] * \mathrm{r},
$$

in which ICWB: interest of the capital of water buffaloes (USD); VBWB: value of breeding water buffalo (USD); BVWB: butchery value of water buffalo (USD); and $\mathrm{r}$ : interest rate $(5 \%)$.

Three per cent of variable cost were calculated as general-management costs (Kiral et al., 1999). Unit cost of milk $(1 \mathrm{~kg})$ was calculated by the potential residue method (Kıral, 1993):

$$
\mathrm{UCM}=(\mathrm{PC}-(\mathrm{VYWBC}+\mathrm{FI})) / \mathrm{TMP},
$$

in which UCM: unit cost of milk (kg/USD); PC: production cost of water buffalo farming (USD); VYWBC: value of young water buffalo calf (USD); FI: fertilizer income of farms (USD); and TMP: amount of water buffalo milk produced $(\mathrm{kg})$

\section{Results}

It is important to understand the socio-economic characteristics of water buffalo farmers in the study area. This was done with the hope of identifying those characteristics that may impact and also help to explain the farming activities of the area. The characteristics considered were age, educational attainment, household size, land acquisition type, farming experience, agricultural land, and farm output sizes.

The mean of household size is seven persons per house (Table 2), which indicates the study area was commonly an extended family. Group III was the modal populated group with about eight persons per family. A total of $50.26 \%$ of this population were women and $49.74 \%$ was men. The age ranges of $0-6,7-14,15-49$, and 50 years or more accounted for $2.7 \%, 4.97 \%, 68.14 \%$, and $24.2 \%$ of the population, respectively (Table 2). Water buffalo farmers were in their economic active age. Most family members were relatively young, (about $68.14 \%$ were between 15 49 years), suggesting high quality of labour, which may positively affect productivity of the farm business, since it will be very easy for the young to adopt new innovations.

Regarding the educational level of the family in the study area (Table 3), about $10.16 \%$ had no formal education, $39.36 \%$ had primary education, whilst $14.13 \%$ had secondary school education. Furthermore, $13.17 \%$ of the respondents had high school education, while $4.13 \%$ had their formal education up to college and university, respectively. Almost $19.05 \%$ of family members were literate, only knowing how to read and write. Group II had the highest rate of illiterates. Group IV had the highest

Table 2 - Family size according to age and gender at the farms

\begin{tabular}{lccccccc}
\hline $\begin{array}{l}\text { Group of } \\
\text { farms }\end{array}$ & $\begin{array}{c}0-6 \\
\text { years }\end{array}$ & $\begin{array}{c}7-14 \\
\text { years }\end{array}$ & $\begin{array}{c}15-49 \\
\text { years }\end{array}$ & $\begin{array}{c}50 \text { and } \\
\text { above }\end{array}$ & Male & Female & Total \\
\hline \multicolumn{7}{c}{$\mathrm{N}$} \\
I & 0.00 & 0.18 & 4.44 & 2.15 & 3.21 & 3.56 & 6.76 \\
II & 0.4 & 0.4 & 3.83 & 0.73 & 2.73 & 2.64 & 5.37 \\
III & 0.16 & 0.77 & 5.46 & 1.85 & 4.79 & 3.44 & 8.23 \\
IV & 0.17 & 0.19 & 5.35 & 1.94 & 3.68 & 3.97 & 7.65 \\
Average & 0.18 & 0.33 & 4.55 & 1.62 & 3.36 & 3.32 & 6.68 \\
& & & & 0 & & & \\
I & 0.00 & 2.61 & 65.65 & 31.74 & 47.39 & 52.61 & 100.00 \\
II & 7.47 & 7.45 & 71.42 & 13.66 & 50.88 & 49.12 & 100.00 \\
III & 1.91 & 9.34 & 66.33 & 22.42 & 58.18 & 41.82 & 100.00 \\
IV & 2.22 & 2.45 & 69.96 & 25.37 & 48.07 & 51.93 & 100.00 \\
Average & 2.70 & 4.97 & 68.14 & 24.20 & 50.26 & 49.74 & 100.00 \\
\hline
\end{tabular}

R. Bras. Zootec., 45(7):400-408, 2016 
education at university level; $9.70 \%$ more than the other groups.

The potential of the family labour force and the use of the family labour force were calculated in male labour force. The number of working days in Muş was estimated as 300 days. The average family working days per family was 936.91 male working days. The idle labour force was 731.49 male working days. The potential family labour force was 1668.4 male labour units (Table 4). Labour was mainly supplied by family.

The results revealed that the age of the respondents ranges between 18 and $60+$ years. The mean age was 55.60, while group III had the modal age class of 61.08 years. The mean educational level was 4.11 years, while group II had the modal educational level of 4.77 years.

The average farming experience amounted to 26.89 years, but group IV had the highest farming experience, 35.00 years, and group II had the lowest, averaging 15.93 years (Table 5). Experience is expected to increase the knowledge and output of farmers.

The average farm size in the study area is 12.08 ha, with group IV having the largest farm size of about 29.97 ha. A total of 7.05 ha of these lands were dry lands, whereas 5.03 ha of the lands were irrigated. It was stated that with the Alpaslan 2 Dam and the Irrigation of Muş Project, the area of irrigated land will increase. The average plot per farms was $2.63 \mathrm{ha}$, and this increased according to farm size.

The number of animals per farm was 15.33 head, and $89.76 \%$ of these animals were bovine, while $10.24 \%$ of them were sheep and goats. About $73.47 \%$ of the bovine animals were water buffaloes. The main reason for water buffalo farming in the region is to provide for the needs of families (82\%). However, there were also farms which had commercial goals (18\%). When the results are evaluated, it can be said that most of the farms were family farms. As the size of the farms increased, commercial purposes also increased. Mostly, small farms were trying to cover their own needs. Usually, small farms had water buffaloes in addition to cattle, sheep, and goats; this was because they wanted to preserve the tradition of water buffalo farming.

The number of water buffaloes per farms was 10.11 head. Of these, 1.29 were males, 4.95 were females, 1.69 were young male calves, and 4.56 were young female calves. The average number of water buffaloes in milk was 4.56 head.

The lactation period for water buffaloes in the region was 211.60 days. Annual milk production per water buffalo was $954.52 \mathrm{~kg}$, and the average milk production per farms was calculated as $4355.80 \mathrm{~kg}$ (Table 6).

Feed was given outside of the pasturing period. Approximately $25.13 \%$ of the feed given was concentrate, $72.96 \%$ was roughage, and $1.91 \%$ was grain feed. Hay and alfalfa were mostly used as roughage. About $64.71 \%$ of the feed was produced by the farms and $35.29 \%$ of the feed was purchased (Table 7).

At an enterprise, the various inputs that are used for production activities and expenditures for services constitute

Table 3 - Education level of families at the farms

\begin{tabular}{|c|c|c|c|c|c|c|c|c|c|c|}
\hline \multirow{3}{*}{ Education level } & \multicolumn{8}{|c|}{ Group of farms } & \multirow{2}{*}{\multicolumn{2}{|c|}{ Average }} \\
\hline & \multicolumn{2}{|c|}{$\mathrm{I}$} & \multicolumn{2}{|c|}{ II } & \multicolumn{2}{|c|}{ III } & \multicolumn{2}{|c|}{ IV } & & \\
\hline & $\mathrm{N}$ & $\%$ & $\mathrm{~N}$ & $\%$ & $\mathrm{~N}$ & $\%$ & $\mathrm{~N}$ & $\%$ & $\mathrm{~N}$ & $\%$ \\
\hline Illiterate & 0.28 & 8.30 & 0.42 & 15.53 & 0.46 & 11.32 & 0.24 & 5.97 & 0.34 & 10.16 \\
\hline Literate & 0.91 & 27.07 & 0.55 & 20.50 & 0.35 & 8.49 & 0.47 & 11.94 & 0.64 & 19.05 \\
\hline Primary school & 1.10 & 32.75 & 1.03 & 38.51 & 2.15 & 52.83 & 1.62 & 41.05 & 1.32 & 39.36 \\
\hline Secondary school & 0.43 & 12.66 & 0.37 & 13.67 & 0.65 & 16.04 & 0.62 & 15.67 & 0.47 & 14.13 \\
\hline High school & 0.50 & 14.85 & 0.32 & 11.80 & 0.35 & 8.49 & 0.62 & 15.67 & 0.44 & 13.17 \\
\hline University & 0.15 & 4.37 & 0.00 & 0.00 & 0.12 & 2.83 & 0.38 & 9.70 & 0.14 & 4.13 \\
\hline Total & 3.37 & 100.00 & 2.68 & 100.00 & 4.08 & 100.00 & 3.94 & 100.00 & 3.35 & 100.00 \\
\hline
\end{tabular}

Table 4 - Potential, idle, and used labour force at the farms

\begin{tabular}{|c|c|c|c|c|c|c|}
\hline \multirow{2}{*}{ Group of farms } & \multicolumn{2}{|c|}{ Family labour force used } & \multicolumn{2}{|c|}{ Idle family labour force } & \multicolumn{2}{|c|}{ Potential family labour } \\
\hline & Quantity (mlu) & Rate (\%) & Quantity (mlu) & Rate $(\%)$ & Quantity (mlu) & Rate $(\%)$ \\
\hline I & 725.88 & 46.23 & 844.36 & 53.77 & 1570.24 & 100.00 \\
\hline II & 795.92 & 55.54 & 637.22 & 44.46 & 1433.13 & 100.00 \\
\hline III & 1401.06 & 67.76 & 666.56 & 32.24 & 2067.62 & 100.00 \\
\hline IV & 1252.87 & 63.45 & 721.75 & 36.55 & 1974.62 & 100.00 \\
\hline Average & 936.91 & 56.16 & 731.49 & 43.84 & 1668.40 & 100.00 \\
\hline
\end{tabular}

mlu - male labour unit. 
Table 5 - Age, work experience, and education level of farmers

\begin{tabular}{lccc}
\hline Group of farms & $\begin{array}{c}\text { Age } \\
\text { (years) }\end{array}$ & $\begin{array}{c}\text { Education level } \\
\text { (years) }\end{array}$ & $\begin{array}{c}\text { Work experience } \\
\text { (years) }\end{array}$ \\
\hline I & 60.09 & 3.59 & 31.76 \\
II & 45.13 & 4.77 & 15.93 \\
III & 61.08 & 3.46 & 28.85 \\
IV & 60.88 & 4.47 & 35.00 \\
Average & 55.60 & 4.11 & 26.89 \\
\hline
\end{tabular}

production costs. Production costs provide important information for the designation of resource demand of production activities, resource use, expenditure and planning, and policy making. Thus, it is very important to determine production costs correctly. However, calculation of production costs is difficult and complicated. Therefore, the production process was examined in detail and the

Table 6 - Average number of water buffalos to milk, lactation period, quantity, and efficiency of milk at examined farms

\begin{tabular}{|c|c|c|c|c|c|}
\hline \multirow{2}{*}{ Indicator } & \multicolumn{4}{|c|}{ Group of farms } & \multirow{2}{*}{ Average } \\
\hline & I & II & III & IV & \\
\hline Water buffalos to milk (head) & 0.76 & 2.77 & 8.77 & 12.12 & 4.56 \\
\hline Yield of milk per water buffalo (kg/year) & 496.61 & 1218.91 & 1491.11 & 1219.20 & 954.42 \\
\hline Lactation period (day/year) & 162.35 & 239.00 & 242.31 & 238.24 & 211.60 \\
\hline Quantity of milk (kg/year/farm) & 379.76 & 3372.34 & 13075.83 & 14773.74 & 4355.80 \\
\hline
\end{tabular}

Table 7 - Use of feed purchased and provided by farms

\begin{tabular}{|c|c|c|c|c|c|c|}
\hline \multirow{2}{*}{ Group of farms } & \multicolumn{2}{|c|}{ Purchased } & \multicolumn{2}{|c|}{ Provided by farms } & \multicolumn{2}{|c|}{ Total feed } \\
\hline & Quantity (kg) & $\%$ & Quantity (kg) & $\%$ & Quantity (kg) & $\%$ \\
\hline I & 3429.41 & 40.55 & 5028.53 & 59.45 & 8457.94 & 100.00 \\
\hline II & 10036.67 & 38.79 & 15835.00 & 61.21 & 25871.67 & 100.00 \\
\hline III & 39153.85 & 46.58 & 44903.85 & 53.42 & 84057.69 & 100.00 \\
\hline IV & 39741.18 & 40.82 & 57617.65 & 59.18 & 97358.82 & 100.00 \\
\hline Average & 12817.02 & 35.29 & 23502.87 & 64.71 & 36319.89 & 100.00 \\
\hline
\end{tabular}

Table 8 - Production cost of water buffalo farming

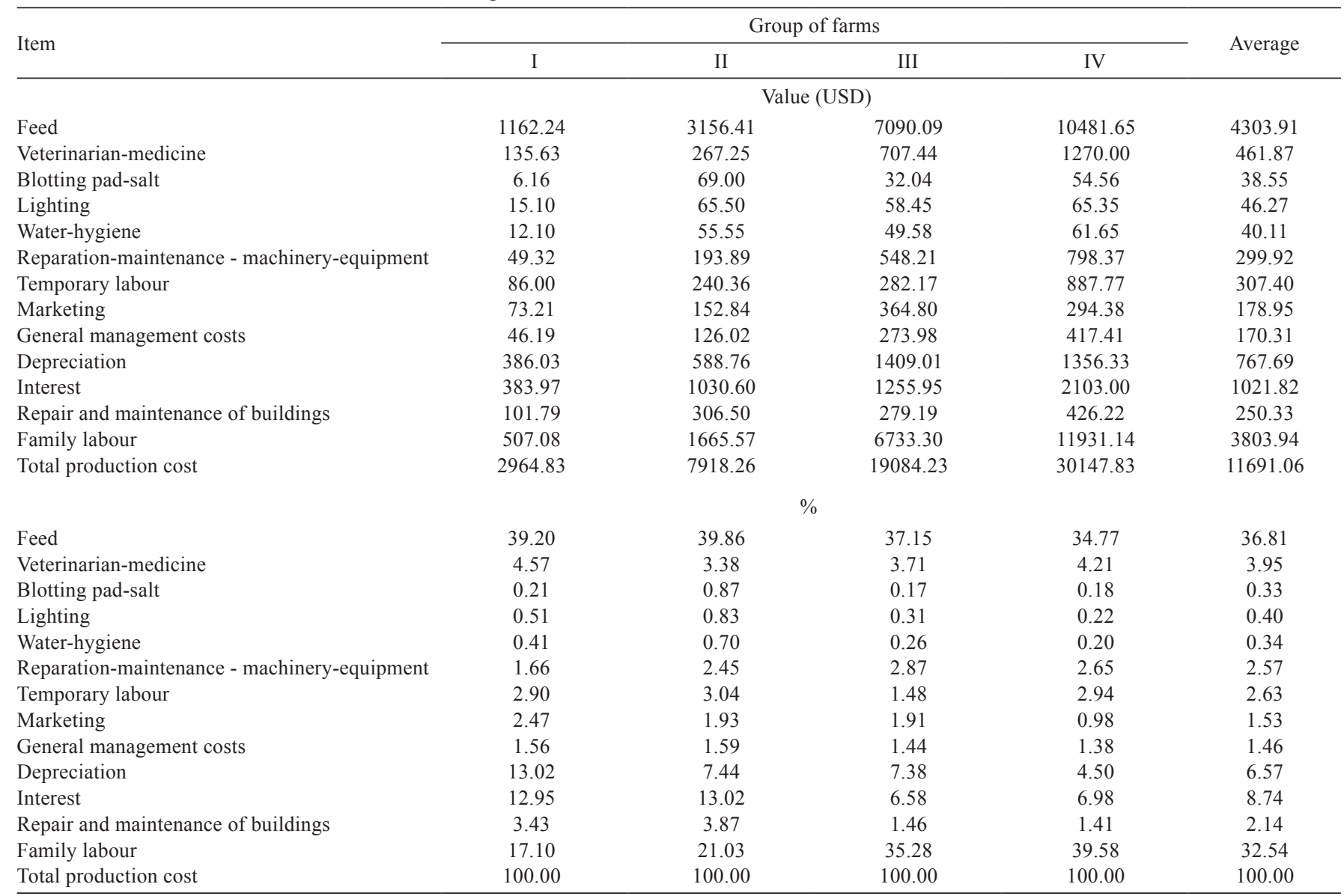


quantity of fixed and variable inputs was determined. Production costs can be divided into two groups: fixed costs and variable costs. Nonetheless, in the long term, fixed costs can be counted as variable costs (Y1lmaz, 2010).

On average, $51.44 \%$ of total production costs (USD11691.06) per farm were fixed costs and $48.56 \%$ of production costs were variable costs. Production costs increased in parallel with the size of the farms. The variable cost items in the water buffalo production were feed, veterinarian-medicine, blotting pad-salt, lighting, water-hygiene, reparation-maintenance of machinery and equipment, temporary labour, and marketing. The variable costs were those which increase or decrease depending on the animal size. Feed cost constitutes the highest modal, with $36.81 \%$ of the total production cost followed by veterinarian-medicine cost with $3.95 \%$ and temporary labour cost, which amounted to $2.63 \%$ of the total cost (Table 8).

The fixed costs in water buffalo farming were administrative cost, interest, repair and maintenance of building, family labour, and depreciation cost. Family labour cost was calculated as $32.54 \%$, followed by $8.74 \%$ and $6.57 \%$ as interest and depreciation cost, respectively, in total cost (Table 8).

Table 9 - Gross production values of the farms

\begin{tabular}{lcccc}
\hline Group of farms & $\begin{array}{c}\text { Plant } \\
\text { production }\end{array}$ & $\begin{array}{c}\text { Other animal } \\
\text { production }\end{array}$ & $\begin{array}{c}\text { Water } \\
\text { buffalos }\end{array}$ & Total \\
\hline Value (USD) & & \\
I & 6391.54 & 7432.94 & 2997.24 & 16821.71 \\
II & 6798.61 & 2574.89 & 8527.04 & 17900.54 \\
III & 20625.71 & 8387.89 & 29910.01 & 58923.61 \\
IV & 37034.77 & 7864.69 & 49770.88 & 94670.35 \\
Average & 14031.87 & 6092.65 & 16943.11 & 37067.63 \\
& & & & \\
I & 38.00 & 44.19 & 17.82 & 100.00 \\
II & 37.98 & 14.38 & 47.64 & 100.00 \\
III & 35.00 & 14.24 & 50.76 & 100.00 \\
IV & 39.12 & 8.31 & 52.57 & 100.00 \\
Average & 37.85 & 16.44 & 45.71 & 100.00 \\
\hline
\end{tabular}

The gross output value in the examined farms was calculated as USD37067.63. The value of plant production constituted $37.85 \%$ of total gross production value for an average farm, while the value of animal production constituted $62.15 \%$. Water buffalo production value had the highest share, with $45.71 \%$ (Table 9). Also, milk production value had the highest value among water buffalo production value, with $74.84 \%$.

The gross production value (GPV) in the study area ranged from USD2997.24 to USD49770.88. The mean average gross production value amounted to USD16943.11. Gross margin also varied from USD1457.51 to USD35857.22, with USD11266.18 being the average mean of the gross margin. This rate increased with the size of the farms. The variation of absolute profit ranged from USD32.38 to USD19623.07, while the absolute profit mean average was calculated as USD5252.05. Absolute profit per water buffalo was USD425.70. These numbers increased with the size of the farms. The relative profit also varied from 1.01 to 1.65 with 1.45 as the average mean of the relative profit (Table 10).

The relative profit was calculated as 1.45 on the average of the farms. This means that the surveyed buffalo farms gained 149 units GPV for the 100 unit production cost. In other words, the farms involved in the buffalo production gained USD1.45 GPV for their USD1.00 production cost and therefore earned USD0.45 profit.

The cost of milk per unit $(1 \mathrm{~kg})$ was calculated as USD0.64 per farms. The cost of milk varied from USD0.40 to USD0.84 (Table 10).

\section{Discussion}

According to statistical data from the FAO (2015), water buffalo farming is common in 34 countries in the world. The number of water buffaloes in these countries increased by $99.5 \%$, from 97.3 million (between 1961 and 1970) to 194.1 million (between 1961 and 2010). The

Table 10 - Gross margin, absolute and relative profit, and costs of milk production by water buffalo farms

\begin{tabular}{lcccc}
\hline \multirow{2}{*}{ Indicator } & \multicolumn{3}{c}{ Group of farms } & Average \\
\cline { 2 - 4 } & I & II & III & IV \\
\hline Variable costs (USD) & 1539.84 & 4200.84 & 9132.82 & 13913.81 \\
Production cost (USD) & 2964.83 & 7918.26 & 19084.23 & 30147.83 \\
Gross production value (USD) & 2997.24 & 8527.04 & 29910.01 & 49770.88 \\
Gross margin (USD) & 1457.51 & 4326.30 & 20777.23 & 35857.22 \\
Gross margin per water buffalo (USD) & 857.29 & 600.31 & 1216.26 & 1691.06 \\
Absolute profit (USD) & 32.38 & 608.80 & 10825.76 & 1345.29 \\
Absolute profit per water buffalo (USD) & 19.05 & 84.47 & 633.72 & 19623.07 \\
Relative profit & 1.01 & 1.08 & 1.57 & 736.21 \\
Cost of milk production by unit (USD/kg) & 0.84 & 0.63 & 0.46 & 1.65 \\
\hline
\end{tabular}


largest share in water buffalo farming belongs to India, with $57.53 \%$ in 2010 . India is followed by Pakistan, with $15.86 \%$, and China, with $12.16 \%$. Initially, China was the second country in water buffalo farming after India. However, with time, because of the social structure, Pakistan became the second country. When we look at the periods analysed, we can see that the number of water buffaloes has increased 13 times in Brazil, eight times in Italy, and four times in Nepal. The number of water buffaloes in Turkey in 2010 constituted $0.04 \%$ of the total number of water buffaloes in the world. During the period of 1961-1970, Turkey had $1,196,066$ water buffaloes, but this number decreased by $95 \%$ and Turkey had 84,726 water buffaloes in 2010. In Turkey, the buffalo population is only of the Anatolian breed and Italian semen was introduced in Ilikpinar village (Hatay), for the local population of buffaloes in order to improve genetic and milk productivity in 2002 (Sekerden et al., 2003). Aiming to protect the numbers of buffaloes and improve milk and fertility of buffalo breeds, the Anatolian Water Buffalo Breeding Project has been performed in Turkey in 2011. Buffaloes are an age-old component of the livestock heritage of Turkey and are an important part of the national domestic livestock genetic resources and biodiversity (Yilmaz et al., 2012).

The majority of the buffalo farmers were the middleand old-aged. The education level of buffalo farmers was low. In the study areas, $47 \%$ of the selected farmers were engaged only with buffalo rearing and crop farming, followed by rearing other animal species. Contribution of buffalo farming was the highest to their GPV and it captured $45.71 \%$ of the GPV. Field crops production was the second, and its contribution to the GPV of farmers was $37.85 \%$. Farmers received animal husbandry support or subsidy for buffalo rearing from government sources $(3.43 \%$ of the GPV of total buffaloes). Relative profit must be greater than one (1) and, based on the above result, relative profit was more than 1 (1.45), which indicates that buffalo production in the study area was profitable. The average gross profit per water buffalo was USD913.17. But income per person of the interviewed farmers was lower than the average of Turkey. It was determined that, to contribute to the family income, some members of the family farmers were working in non-agricultural jobs out of province. Some family members were involved in agriculture labour selling.

Buffaloes were raised mainly for milk and meat. Family members of farmers worked full time on their holdings. All farmers practice buffalo and crop farming. A total of $52.1 \%$ of farms also had income from other animals (cattle and small ruminants). Buffalo farming is the most important income for farmers surveyed in this study. Of the total,
$30.5 \%$ sold their products (milk and milk products such as yogurt, butter, and cheese) in the local market, which increased production costs because of transportation, other fees, and taxes; and $69.5 \%$ of farms sold their products to wholesalers.

The average milk production of buffaloes in this study area was $954.42 \mathrm{~kg} /$ year. Lactation length was 230 days, with an average lactation milk yield of $1000 \mathrm{~kg}$ in Turkey (Borghese and Mazzi, 2005). Günlü et al. (2010) reported that milk production of buffalo in Afyonkarahisar, west region of Turkey, was $1078.59 \pm 21.85 \mathrm{~kg} / \mathrm{year}$. Han et al. (2015) noticed that the milk yield of Anatolian Water Buffaloes was $837.8 \pm 12.10$ and $952.4 \pm 15.40 \mathrm{~kg}$ in 2012 and 2013, respectively, in Diyarbakir. Total lactation milk yield average was $1567.3 \mathrm{~kg}$ in İstanbul (Soysal et al., 2015). Soysal (2015) showed the results of the new Based Anatolian Buffalo Breeding project on 25,000 buffaloes in 16 provinces, where the lactation yield was $852 \mathrm{~kg}, 952 \mathrm{~kg}$, and $987 \mathrm{~kg}$ in the years 2012, 2013, 2014, respectively.

Riverine breeds produce more milk than the swamp types, and the average milk yield of the riverine breeds is 1800 to $2100 \mathrm{~kg}$ per lactation (Subasinghe et al., 1998). Khan and Akhtar (1999) reported that the average milk production of Nili-Ravi buffaloes was 2020.04 $\pm 44.59 \mathrm{~L}$. Khan et al. (2014) also reported that Azikheli buffalo in Pakistan produces $7.19 \pm 0.18 \mathrm{~L}$ of milk per day. Macedo et al. (2001) found that milk production was $4.52 \mathrm{~kg} /$ day for the Mediterranean breed. Salari et al. (2013) reported that Mediterranean buffalo cows produced $8.47 \mathrm{~kg}$ of milk per head. In this study, buffaloes were of the indigenous type, and milk yield was similar to the findings of a large number of authors for Turkey (Borghese and Mazzi, 2005; Günlü et al., 2010; Han et al., 2015; Soysal, 2015; Soysal et al., 2015).

In the research area, the buffalo feeding system depended on grazing, but grazing was not sufficient for buffaloes from October to April, and so farmers gave complementary feeding to the buffaloes. Farmers kept their buffaloes mainly under a semi-intensive feeding system in the study areas. It could be concluded that the buffalo farmers did not rear their buffaloes in a scientific way, rather following traditional ways. Ligda and Georgoudis (2005) reported that the buffalo rearing system in Greece was grazing during the entire year, and during the period from November to April feed was given to the animals. In Bangladesh, the majority of farmers were fully dependent on grazing (Sarker et al., 2013; Amin et al., 2015).

Water buffalo farming is a more traditional way in the investigated region, and the market and socio-economic conditions of the region are different from the west region of Turkey. In Afyonkarahisar, Günlü et al. (2010) found that 
the most important income source of water buffalo farming was the sale of cream made from water buffalo.

Buffalo breeding is a synonym for low production costs and high levels of productivity (Rocha, 2001). In this study, the feeding cost share was calculated as $36.81 \%$ of total production cost, and family labour was the second important cost (32.54\%). Especially small scale farmers $(85 \%)$ and $59.6 \%$ of interviewed farmers did not purchase concentrate feed for buffalo, except in the scarcity period, the time when they purchase straw or alfalfa only.

Del Giudice (2004) found that the cost factor of production percentage of buffalo farms in Italy was $72 \%$ on feed, $18 \%$ on labour, $5 \%$ on veterinary care and certificates, and the remainder on other costs. Another cost analysis conducted by Günlü et al. (2010) examined the structural features of water buffalo milk farms in Afyonkarahisar, in Turkey. Günlü et al. (2010) found feed costs as 42.84\% and labour costs as $27.48 \%$ in total cost. They found that relative profit was 0.92 . Bardhan et al. (2005) calculated that feeding cost contributed with 60 to $70 \%$ of total cost of milk production. The findings of this study for feed cost share were lower than the findings of Del Giudice (2004), Bardhan et al. (2005), and Günlü et al. (2010).

Çiçek et al. (2009) used Cobb-Douglass production function to analyse the efficient use of inputs in water buffalo farms. They used variables such as concentrate feed and roughage, fattening period, average number of water buffaloes, and usage capacity in models and found stable production outcomes considering the scale.

\section{Conclusions}

Water buffalo production in the study area is a profitable business, and farm size is a significant factor affecting the output of water buffalo production in the study area.

Based on the findings of this study, the following recommendations are made:

Since the farms in the region are small and the prices of inputs are high, water buffalo farming has not developed enough to reach the level of market-oriented production. Therefore, policies should be made according to the size of farms in the region and more economical production can be achieved by solving market-related problems.

The milk productivity of water buffaloes in the region is low and it is more obvious especially on small farms. Thus, milk yield could be increased by animal improvements. In this way, milk yield could reach a desired level.

Maintaining traditional methods in water buffalo farming prevents targeted efficiency expectations. Therefore, transferring new modern husbandry techniques to producers is an important issue for policy makers.

Lack of information on benefits of water buffalo dairy products creates an important problem in the marketing of these products for farmers. Therefore, infrastructures required for promotion of water buffalo dairy products should be prepared and policies related to promotional advertisement should be implemented.

To reach the desired level of water buffalo farming, incentives on water buffalo should be maintained, policies should be improved by using input subsidies, producers should be trained on water buffalo farming, and improvements in policies of promotion and benefits of water buffalo dairy products may be useful for establishing a water buffalo culture in Turkey.

\section{Acknowledgments}

The authors thank the support provided by Süleyman Demirel University Scienctific Research and Projects Coordination Unit (Project number: SDÜ BAP 3591-YL2-13).

\section{References}

Açıl, F. and Demirci, R. 1984. Agricultural economy. Ankara University Agriculture Faculty Publications, No. 880, 372p. Ankara (in Turkish).

Amin, M. R.; Siddiki, M. A.; Kabir, A. K. M. A.; Faruque, M. O. and Khandaker, Z. H. 2015. Status of buffalo farmers and buffaloes at Subornochar upozila of Noakhali district in Bangladesh. Progressive Agriculture 26:71-78.

Aras, A. and Çakır, C. 1975. Economic analysis of farm in Gediz Irrigation Project. Ege University Agriculture Faculty Publications, No. 211, 69p. İzmir (in Turkish).

Bardhan, D.; Srivastava, R. S. L. and Dabas, Y. P. S. 2005. Economics of buffalo milk production in Tarai area of Uttaranchal. Indian Journal of Dairy Science 58:129-133.

Borghese, A. and Mazzi, M. 2005. Buffalo population and strategies in the world. p.1-39. In: Buffalo production and pesearch. Borghese, A., ed. REU Technical Series 67. Food and Agriculture Organization of The United Nations, Rome, Italy.

Canbolat, Ö. 2012. Buffalo breeding and current situation in Turkey. Journal of Tarım Türk 30:176-180 (in Turkish).

Çiçek, H.; Günlü, A. and Tandoğan, M. 2009. Production Function analysis of buffalo fattening enterprises in Afyonkarahisar Region of Turkey. Journal of Animal and Veterinary Advances 8:2158-2163.

Çiçek, A. and Erkan, O. 1996. Research and sampling methods in agricultural economics. Gaziosmanpaşa University Agriculture Faculty Publications, No:12. Tokat (in Turkish).

Del Giudice, T. 2004. An initial estimate of the cost of production of meat from pregnant buffaloes. Bubalus Bubalis 10:24-28.

Erkuş, A.; Eliçin, A.; Özçelik, A.; Turan, A.; Tanrıvermiş, H. and Gündoğmuş, E. 1996. Comparative economic analysis of dairy cattle farms which engaged import and hybrid culture in Tekirdag Province. Ziraat Yüksek Mühendisleri Birliği ve Vakfi Publications No.14, 138p. Ankara (in Turkish). 
FAO - Food and Agriculture Organization. 2015. Statistical database. Available at: <http://fostat.fao.org $>$. Accessed on: May 1, 2015.

Günlü, A.; Çiçek, H. and Tandoğan, M. 2010. Socio-economic analysis of dairy buffalo enterprises in Afyonkarahisar province in Turkey. Journal of Food, Agriculture \& Environment 8:689-691.

Han, Y.; Tez, Ş.; İpek, P.; Vural, M. E.; Karataş, A.; Keskin, B. and Bakır, G. 2015. Some yield features of Anatolian water buffaloes grown people's hand in Diyarbakir province. p.129. In: Proceedings of the 7th Balkan Conference on Animal Science, Sarajevo.

Khan, R. N. and Akhtar, S. 1999. Production characteristics of NiliRavi buffaloes. Asian-Australasian Journal of Animal Sciences 12:56-60.

Khan, M.; Saleem, M.; Rahim, I.; Khan, H.; Gohar, A.; Ahmad, S.; Salim, M.; Ali, Q. and Farmanullah, 2014. Assessment of morphometric, productive and reproductive characteristics of Azikheli buffalo in Swat valley in northern Pakistan. Life Science Journal 11:1-8.

Kıral, T. 1993. Economic analysis of cattle fattening enterprises supported by Turkey Sugar Factories Inc. of Fattening Regional Chief in Ankara. Ankara University Agriculture Faculty Publications, No.1289, 80p. Ankara (in Turkish).

Kıral, T.; Kasnakoğlu, H.; Tatlıdil, F. F.; Fidan, H. and Gündoğmuş, E. 1999. The cost calculation methodology and database directory for agricultural products. TEAE Publications, Publication No: 37, 143p. Ankara (in Turkish).

Ligda, C. H. and Georgoudis, A. 2005. Adaptation of buffalo production systems towards the market demand for certified quality products. Journal of Tekirdag Agricultural Faculty 2:124-126.

Macedo, M. P.; Wechsler, F. S.; Ramos, A. D.; Amaral, J. B.; Souza, J. C.; Resende, F. D. and Oliveira, J. V. 2001. Chemical composition and production of milk from Mediterranean buffalo cows raised in western of São Paulo State, Brazil. Revista Brasileira de Zootecnia 30:1084-1088.

Rehber, E. and Çetin, B. 1998. Agricultural economics. Uludağ University Güçlendirme Vakfı Publications, No. 134, VIPAŞ A.Ş. Publications, No. 10, 317p. Bursa (in Turkish).

Rocha, L. 2001. Buffalo production systems in Americas. p.74-86. In: Proceedings of the Sixth World Buffalo Congress, Maracaibo, Zulia, Venezuela.

Salari, F.; Altomonte, I. and Martini, M. 2013. Buffalo milk: a case study of some parameters related to milk production. Large Animal Review 19:17-20.
Sarker, S.; Hossain, M. M. and Amin, M. R. 2013. Socioeconomic status of buffalo farmers and the management practices of buffaloes in selected areas of Bagerhat district of Bangladesh. Bangladesh Journal of Animal Science 42:158-164

Sekerden, Ö.; Borghese, A.; Köroslu, M.; Uyar, A.; Uras, H. and Ziya Güzey, Y. 2003. First oestrus synchronization and artificial insemination studies and effect of PRID treatment on conception rate in Anatolian buffaloes. p.3. In: Proceedings of the Second National Congress on Buffalo Improvement, vol. 2830, Monterotondo, Roma.

Soysal, İ. 2006. Production of water buffalo and products. Tekirdağ University, Agriculture Faculty Department of Animal Science, Lecture note, Tekirdağ (in Turkish).

Soysal, M. İ. 2015. Anatolian water buffalo husbandry in Turkey. p.6. In: Proceedings of the 8th Asian Buffalo Congress, Istanbul.

Soysal, M. İ.; Gürcan, E. K. and Aksel, M. 2015. The comparison of lactation curve with different models in Anatolian water buffalo. p.90. In: Proceedings of the 7th Balkan Conference on Animal Science, Sarajevo.

Subasinghe, D. H. A.; Horadogoda, N. U.; Abeygunawardena, H. and Siriwardene, J. A. de S. 1998. Water buffalo-improved utilisation through new technologies. National Science Foundation, Sri Lanka.

TUIK - Turkish Statistical Institute. 2014. Muş with selected indicators in 2013. Publication Number: 4320, 176p. TUIK, Ankara (in Turkish).

TUIK - Turkish Statistical Institute. 2015. Statistical database. Available at: $<\mathrm{http} / / /$ www.tuik.org.tr>. Accessed on: Oct. 1, 2015.

Yamane, T. 2001. Elementary sampling theory. Literatür Publications, Publications No: 53. Translated: Esin, A.; Aydın, C.; Bakır, M. A. and Gürbüzsel, E. İstanbul (in Turkish).

Yıldırım, İ. and Şahin, A. 2003. Economic analysis of dairy cattle enterprises in Central District of Van Province. Van Commodity Exchange Publication, No.1, 50p. Van (in Turkish).

Y1lmaz, H. 2010. Economic and social effects of support through cooperatives to dairy farms: Case of Adana province. PhD Thesis. Çukurova University, Institute of Natural and Applied Sciences, Adana (in Turkish).

Yilmaz, O.; Ertugrul, M. and Wilson, R. T. 2012. Domestic livestock resources of Turkey Water buffalo. Tropical Animal Health and Production 44:707-714. 